NOTE

\title{
OIE white spot syndrome virus PCR gives false-positive results in Cherax quadricarinatus
}

\author{
Kerry Claydon, Bradford Cullen, Leigh Owens* \\ Microbiology and Immunology, James Cook University, Townsville, Queensland 4811, Australia
}

\begin{abstract}
White spot syndrome virus (WSSV) is an intranuclear bacilliform virus (IBV) that is a serious, notifiable crustacean pathogen. The Office International des Epizooties (OIE) PCR protocol for WSSV uses primer sets initially developed by Lo et al. (1996). It yields a first-step PCR amplicon of $1441 \mathrm{bp}$ and a nested PCR amplicon of $941 \mathrm{bp}$. An amplicon (941 bp) purported to specifically detect WSSV was obtained when using template DNA extracted from Cherax quadricarinatus in a WSSV PCR detection protocol recommended by the OIE. Sequencing and analysis of the $941 \mathrm{bp}$ amplicon and an occasional 550 bp amplicon from C. quadricarinatus revealed no phylogenetic relationship with WSSV, and suggested a possible lack of sufficient primer specificity for WSSV in the OIE test. This suggestion was supported by the fact that the OIE outer primer sequence (146F1) was present in both the forward and reverse position of the $941 \mathrm{bp}$ and the forward position of the $550 \mathrm{bp}$ nested amplicons from $C$. quadricarinatus. As WSSV is a notifiable pathogen, the consequences of false-positive results are harsh in WSSV-free zones and can lead to incorrect quarantine and unnecessary destruction of animals. Therefore, urgent attention and revision is necessary for the current OIE PCR protocol for WSSV detection.
\end{abstract}

KEY WORDS: Cherax quadricarinatus · Intranuclear bacilliform virus · White spot syndrome virus · PCR

Resale or republication not permitted without written consent of the publisher

\section{INTRODUCTION}

White spot syndrome virus (WSSV) is the most widely studied aquatic invertebrate virus, and is typically found to infect prawn and crab species. WSSV has the potential to cause $100 \%$ mortality in these crustaceans in 3 to $10 \mathrm{~d}$, and has been responsible for several prawn epizootics around the world (Inouye et al. 1994, Takahashi et al. 1994, Chou et al. 1995, Wongteerasupaya et al. 1995, Karunasagar et al. 1997). Like the intranuclear bacilliform virus (IBV) of Cherax quadricarinatus, WSSV was previously referred to as a member of the family Baculoviridae, largely due to morphological characteristics of virions (Inouye et al. 1994, Takahashi et al. 1994, Wongteerasupaya et al. 1995, Inouye et al. 1996, Durand et al. 1997). Subsequent genome analysis resulted in placement of
WSSV in a new viral genus (Whispovirus) and family (Nimaviridae) by the International Committee for the Taxonomy of Viruses (ICTV) (van Hulten et al. 2001, Mayo 2002).

Of interest in this study was the relationship between WSSV and IBV of Cherax quadricarinatus. Unconfirmed reports of WSSV detection in grossly and histologically normal C. quadricarinatus using the Office International des Epizooties (OIE) PCR protocol for WSSV in Ecuador and Spain (V. Alday-Sanz pers. comm.) led us to question whether the OIE protocol might cross prime with IBV template. This might be possible, if the 2 viruses turned out to be genetically related, as earlier suggested by morphological similarities. For detection of WSSV, the OIE recommends the use of PCR technology (OIE 2003) based on the protocol initially developed by Lo et al. (1996). Here we 
describe the use of the OIE protocol to screen IBVinfected C. quadricarinatus for cross priming reactions.

\section{MATERIALS AND METHODS}

Viral extraction and DNA purification. Two IBVinfected Cherax quadricarinatus, confirmed via histopathology, were selected for hepatopancreas (HP) and muscle tissue extracts for DNA analysis. Extracts were also taken from a presumptive virus-free $C$. quadricarinatus (Edgerton \& Owens 1997). DNA was extracted from $50 \mathrm{mg}$ samples of tissue using the High Pure PCR Template Preparation Kit (Roche Applied Science) according to the manufacturer's instructions. The only modification was that Proteinase K digestion was carried out at $37^{\circ} \mathrm{C}$ for $24 \mathrm{~h}$.

PCR amplification using decapod specific primers. To verify the quality of extracted DNA, PCR was conducted using decapod-specific primers (Lo et al. 1996) 143F (5'-TGC-CTT-ATC-AGC-TAC-GTT-CGA-TTG-TAG-3') and 143R (5'-TTC-AGA-CGT-TTT-GCA-ACC-ATACTT-CCC-3') expected to yield an amplicon of $848 \mathrm{bp}$.

PCR amplification using the OIE WSSV protocol. Extracted DNA was checked for WSSV by nested PCR, using the first primer set 146F1 (5'-ACT-ACT-AACTTC-AGC-CTA-TCT-AG-3'), 146R1 (5'-TAA-TGCGGG-TGT-AAT-GTT-CTT-ACG-A-3') and the second (inner) primer set 146F2 (5'-GTA-ACT-GCC-CCTTCC-ATC-TCC-A-3') and 146R2 (5'-TAC-GGC-AGCTGC-TGC-ACC-TTG-T-3') designed on the DNA sequence of a cloned PmNOB III 1461 bp SalI DNA fragment of WSSV (Lo et al. 1996). Control reactions containing no template DNA were run for both PCR reactions. No WSSV-positive control was utilised due to lack of availability.

DNA sequencing of PCR products. DNA fragments selected for further analysis were excised from the agarose gels and purified using Promega's Wizard SV Gel and PCR clean-up system according to the manufacturer's instructions. Amplicons were cloned using pGEM $^{\circledR}$-T easy vector plasmid (Promega) according to the manufacturer's instructions. DNA sequencing was carried out using M13 universal primers (Promega) and a Beckman Coulter CEQ dye terminator cycle sequencing quick start kit. Products were analysed with a Beckman CEQ 2000 DNA analysis system at the Advanced Analytical Centre at James Cook University, Townsville. Four forward and 4 reverse sequence reactions from 2 different clones were aligned using Sequencher software (Genecodes Corporation), to give an overall consensus sequence. Sequences obtained were compared to available databases using Basic Local Alignment Search Tool (BLAST) to determine approximate phylogenetic affiliations.

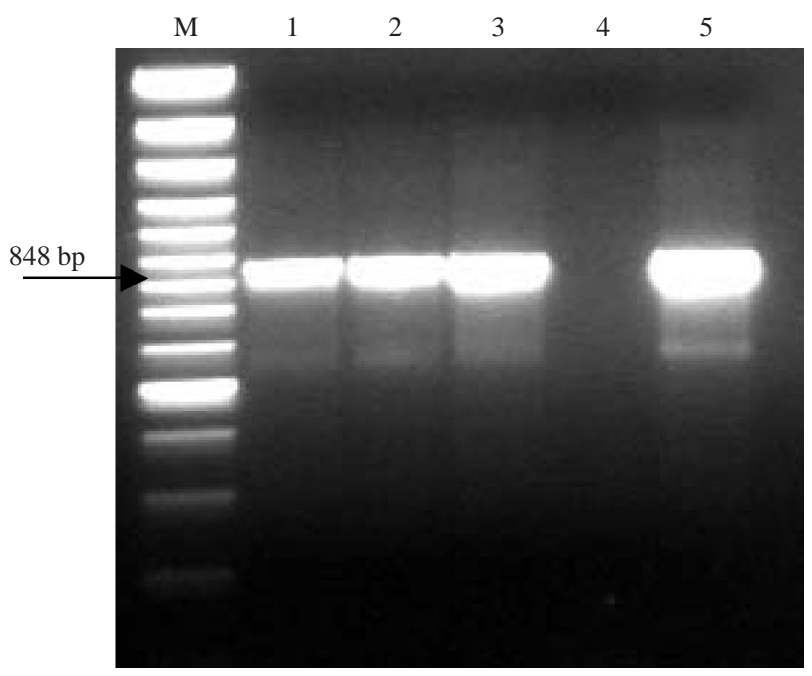

Fig. 1. Detection of decapod DNA by PCR. Lane M: GeneRuler; Lane 1: Crayfish 1A; Lane 2: Crayfish 1B; Lane 3: Crayfish 2; Lane 4: negative control; Lane 5: Penaeus monodon positive control

\section{RESULTS}

\section{Decapod DNA PCR amplification}

The expected 848 bp decapod-specific amplicon was obtained in all HP and muscle tissue extracts. DNA extracted from Penaeus monodon was used as a positive control (Fig. 1).

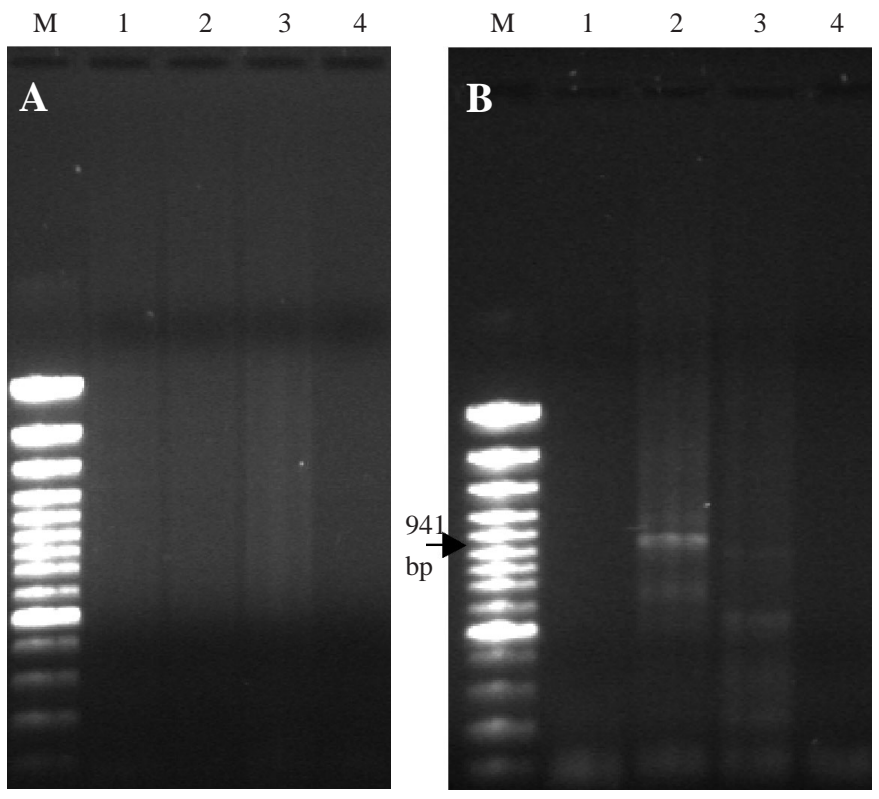

Fig. 2. (A) Outer nested PCR and (B) Inner nested PCR reactions using WSSV primers. Lane M: GeneRuler; Lane 1: Crayfish 1A hepatopancreas; Lane 2: Crayfish 1B hepatopancreas; Lane 3: Crayfish 2 hepatopancreas; Lane 4: negative control 


\section{Analysis of products from PCR amplification using WSSV primers}

No amplicons were visualised in agar gels after the first (outer) PCR reaction (Fig. 2A). However the inner PCR showed a visible product in the HP sample of 1 crayfish (Fig. 2B). The size of the amplicon (941 bp) corresponded to that for a positive WSSV-specific reaction according to the OIE protocol.

Attempts to repeat this visualization were inconsistent. When the annealing temperature was lowered from 55 to $50^{\circ} \mathrm{C}$ in both steps of the nested PCR reaction, no products could be visualised after the first (outer) PCR reaction but the nested PCR step gave repeatable positive results across all crayfish HP samples (Fig. 3). Furthermore, both virus-free and virusinfected HP and muscle extracts gave amplicons. In addition to the expected amplicon of approximately $941 \mathrm{bp}$, an additional, fainter band of approximately $550 \mathrm{bp}$ was obtained with some samples.

\section{DNA sequencing of PCR products}

Cloning, sequencing and analysis of the $941 \mathrm{bp}$ amplicons from 2 samples (GenBank accession numbers AY703870 and AY703871, respectively) revealed no significant nucleotide identity to WSSV or each other. In fact, no phylogenetic relationship was established with database sequences from Cherax quadricarinatus or any organism listed in GenBank. Excluding primer sequences, the sequences of the 941 and 550 bp amplicons were similar, but not identical. Curiously, the sequence for the outer forward primer 146F1 (purportedly specific for the first-step amplicon of the nested PCR reaction) was found at both ends of the $941 \mathrm{bp}$ amplicon and at 1 end of the $550 \mathrm{bp}$ amplicon (Fig. 4).

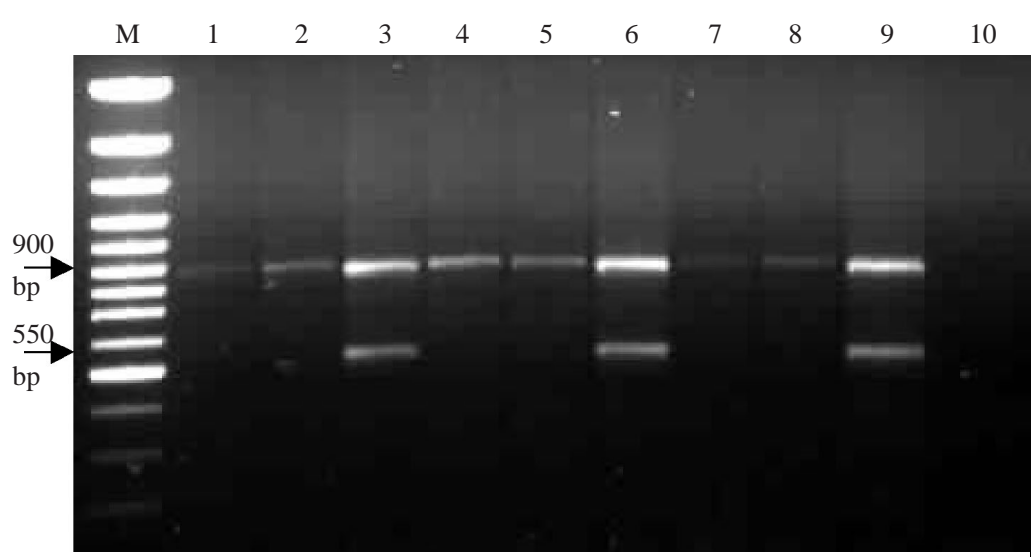

Fig. 3. Inner nested PCR reaction using WSSV primers, with lowered annealing temperature of $50^{\circ} \mathrm{C}$. Lane M: GeneRuler; Lanes 1, 4 and 7: Crayfish 1A hepatopancreas; Lanes 2, 5 and 8: Crayfish 1B hepatopancreas; Lanes 3,6 and 9: Crayfish 2 hepatopancreas; Lane 10: negative control

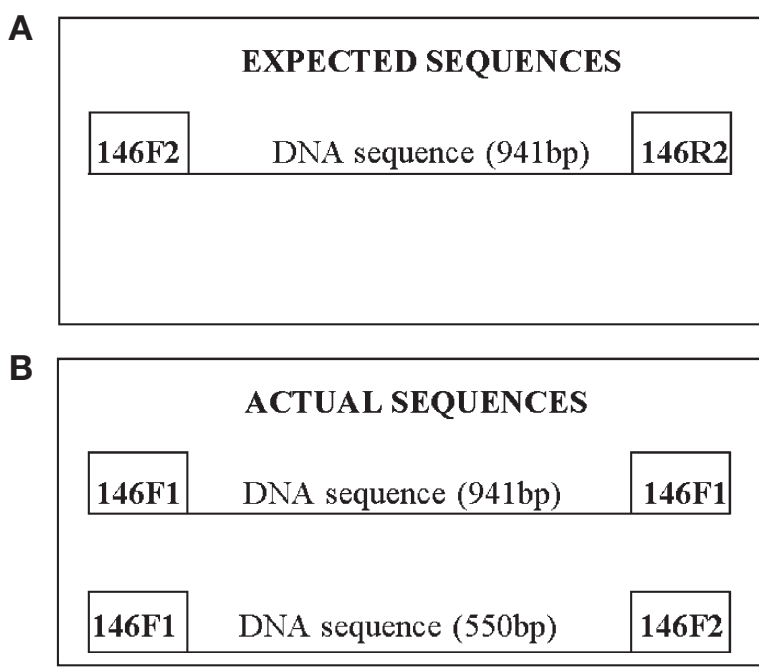

Fig. 4. (A) Primers that should be present at each end of the WSSV 941 bp DNA sequence using the OIE PCR protocol. (B) Actual primers found to be present after DNA sequencing of the approximate 941 and $550 \mathrm{bp}$ amplicons

\section{DISCUSSION}

The sporadic nature of the positive PCR results we obtained using the unmodified OIE protocol (Lo et al. 1996) may have resulted from relatively poor binding of the designed primers (particularly the outer primer 146F1) when carried through 2 amplification rounds.

Whilst the $550 \mathrm{bp}$ amplicon is not of concern, the larger $941 \mathrm{bp}$ amplicon is, because it will be confused with the putative $941 \mathrm{bp}$ WSSV-specific amplicon used to detect WSSV in the OIE PCR protocol. At this juncture, it is not possible to identify the target origin for the PCR amplicons. However, due to amplicons being attained from virus-free crayfish, as well as amplicons from muscle extracts, it appears that these amplicons are not of viral or exclusively HP origin. The origin may in fact be Cherax quadricarinatus DNA or some other cryptic pathogen or commensal of C. quadricarinatus that is present in both the HP and muscle tissues.

The fact that we obtained more consistent false-positive results by lowering the annealing temperature below that recommended in the OIE PCR protocol is another reason for precaution, since laboratory facilities operating old or poorly maintained thermo-cyclers would be more likely to obtain false-positive results with these primer sets. In particular, it is known that the thermal gradient across a PCR block can decay with the outer edges being cooler than the centre. 
This is the first time false-positive results have been confirmed using WSSV primers designed by Lo et al. (1996). In Australia in late 2000, putative WSSV infections were detected in crabs within the Darwin Aquaculture Centre and prawns within the aquaculture facilities of the Northern Territory University (Bernoth 2000) using the OIE protocol. The putative infections were thought to have arisen from the inadvertent use of imported green prawns as feed. Despite the lack of clinical disease, the positive PCR findings resulted in immediate slaughter of all crustaceans at both facilities and the Consultative Committee on Emergency Animal Diseases (CCEAD) agreed to conduct a survey of wild crustaceans (prawns and crabs only) to determine whether WSSV was in Australia (Bernoth 2001). The sampling strategy and testing methods used conformed to published OIE protocols. Positive WSSV results were obtained using the OIE PCR method at a further 3 sites, but parallel samples assessed by bioassay, histology and in situ hybridisation all gave negative results (Bernoth 2002).

Recently, a disease survey by Western Australian Fisheries also found weak positive PCR results in crab samples when using the OIE PCR method of Lo et al. (1996) (Jones 2003). However, re-testing by real-time PCR gave consistently negative results, and Jones (2003) suggested that a possible cause for the false-positive PCR results was non-specific amplicons of the same size as the expected WSSV amplicon.

It is of concern that the OIE PCR protocol for WSSV is currently the recognised international standard for WSSV detection and that it will continue to be used, despite the possibility of false-positive results. Thus, the current OIE PCR protocol for WSSV should be changed or modified. Modification may include minimising the amount of outer primers used for the first nested step in order to reduce carryover in the second nested step. In addition, it may be necessary to sequence the $941 \mathrm{bp}$ amplicon or to carry out a Southern blot analysis with a WSSV-specific probe to confirm detection. Chang et al. (2002) have also suggested that the 146F1/146R1 and 146F2/146R2 primer sets may lack the required sensitivity for PCR diagnosis and are capable of producing false-negative results (Chang et al. 2002).

The consequences of false positives being detected are harsh in WSSV-free zones and can lead to incorrect quarantine and unnecessary destruction of animals or their products. The potential for false-positive PCR results suggests that detection should be confirmed by another detection method. This may include confirmation with a different PCR protocol, sequencing of PCR products, in situ/blot hybridisa- tion and transmission electron microscopy. It is imperative that molecular techniques give accurate and precise results to avoid misdiagnosis and minimise speculation.

\section{LITERATURE CITED}

Bernoth EM (2000) Aquatic animal health. Anim Health Surveillance Q Rep 5:8

Bernoth EM (2001) Aquatic animal health. Anim Health Surveillance Q Rep 6:6

Bernoth EM (2002) Aquatic animal health. Anim Health Surveillance Q Rep 7:4-5

Chang YS, Lo CF, Peng SE, Liu KF, Wang CH, Kou GH (2002) White spot syndrome virus (WSSV) PCR-positive Artemia cysts yield PCR-negative nauplii that fail to transmit WSSV when fed to shrimp postlarvae. Dis Aquat Org 49:1-10

Chou HS, Huang C, Wang CS, Chiang HC, Lo CF (1995) Pathogenicity of a baculovirus infection causing white spot syndrome in cultured penaeid shrimp in Taiwan. Dis Aquat Org 23:165-173

Durand S, Lightner DV, Redman RM, Bonami JR (1997) Ultrastructure and morphogenesis of white spot syndrome baculovirus. Dis Aquat Org 29:205-211

Edgerton B, Owens L (1997) Age at first infection of Cherax quadricarinatus by Cherax quadricarinatus bacilliform virus and Cherax giardiavirus-like virus, and production of putative virus-free crayfish. Aquaculture 152:1-12

Inouye $\mathrm{K}$, Miwa $\mathrm{S}$, Oseko N, Nakano H, Kimura T, Momoyama K, Hiraoka M (1994) Mass mortality of cultured kuruma shrimp Penaeus japonicus in Japan in 1993: electron microscopic evidence of the causative virus. Fish Pathol 29:149-158

Inouye K, Yamano K, Ikeda N, Kimura T, Nakano H, Momoyama K, Kobayashi J, Miyajima S (1996) The penaeid rodshaped DNA virus (PRDV) which causes penaeid acute viremia (PAV). Fish Pathol 31:39-45

Jones JB (2003) Determination of the disease status of Western Australia commercial prawn stocks. Report No. FRDC 98/212, Department of Western Australia Fisheries, North Beach

Karunasagar I, Otta SK, Karunasagar I (1997) Histopathological and bacteriological study of white spot syndrome of Penaeus monodon along the west coast of India. Aquaculture 153:9-13

Lo CF, Leu JH, Ho CH, Chen CH and 8 others (1996) Detection of baculovirus associated with white spot syndrome (WSBV) in penaeid shrimps using polymerase chain reaction. Dis Aquat Org 25:133-141

Mayo MA (2002) A summary of taxonomic changes recently approved by ICTV. Arch Virol 147:1655-1656

OIE (Office International des Epizooties) (2003) Manual of diagnostic tests for aquatic animal diseases, Vol 4.1.2. OIE, Paris

Takahashi Y, Itami T, Kondom M, Maeda M, Fujii R, Tomonaga S, Supamattaya K, Boonyaratpalin S (1994) Electron microscopic evidence of bacilliform virus infection in $\mathrm{Ku}-$ ruma shrimp (Penaeus japonicus). Fish Pathol 29:121-125

van Hulten MC, Witteveldt J, Peters S, Kloosterboer N and 5 others (2001) The white spot syndrome virus DNA genome sequence. Virology 286:7-22

Wongteerasupaya C, Vickers JE, Sriurairatana S, Nash GL and 6 others (1995) A non-occluded, systemic baculovirus that occurs in cells of ectodermal and mesodermal origin and causes high mortality in the black tiger prawn Penaeus monodon. Dis Aquat Org 21:69-77

Submitted: December 9, 2003; Accepted: August 31, 2004

Proofs received from author(s): November 10, 2004 